
SUSUNAN DEWAN REDAKSI

“JURNAL NASIONAL KOMPUTASI DAN TEKNOLOGI INFORMASI (JNKTI)"

\author{
Penanggung Jawab \\ Muhammad Fadhli, S.Kom, M.Kom \\ Ketua Dewan Editor \\ Zulfan, ST, MT \\ Editor Pelaksana \\ Munawir, ST, MT \\ Baihaqi, ST, MT \\ Sekretaris \\ Yeni Yanti, ST, MT \\ Mitra Bestari \\ Prof. Dr. Ir. Yuwaldi Away, M.Sc \\ Dr. Taufiq A. Gani, S.Kom, M.Eng.Sc \\ Dr. Melinda, ST, M.Sc \\ Layout \\ Eka Novendra, ST \\ Penerbit \\ Program Studi Teknik Informatika \\ Universitas Serambi Mekkah \\ Alamat Penerbit
}

Gedung H Fakultas Teknik Universitas Serambi Mekkah

Jl. T. Imum Lueng Bata, Telp. (0651)26160 Batoh - Banda Aceh 


\section{SINOPSIS}

Jurnal Nasional Komputasi dan Teknologi Informasi (JNKTI) merupakan jurnal ilmiah nasional yang diterbitkan oleh Program Studi Teknik Informatika Universitas Serambi Mekkah yang mempublikasikan artikel-artikel ilmiah dalam bidang komputasi dan teknologi informasi.Jurnal ini terbit sebanyak 2 (dua) kali dalam 1 (satu) tahun yaitu pada Bulan April dan Oktober. Bidang-bidang fokus penelitian yang akan dipublikasi dalam jurnal ini antara lain :

- Bidang Rekayasa Perangkat Lunak

- Bidang Jaringan Komputer

- Bidang Multimedia dan Pengolahan Citra Digital

- Bidang Komputasi

- Multidisiplin ilmu lainnya yang relevan 
DAFTAR ISI

JNKTI VOL.2 NO.1, APRIL 2019

Studi Simulasi Aerodinamika Airfoil dan Prediksi

$1-8$

Performa Picth Tetap Turbin Angin Poros Tegak (Darrieus)

terhadap Output Power untuk Aplikasi Kecepatan Angin Rendah

Wahyu Priyanto ${ }^{1}$, Ira Devi Sara ${ }^{2}$, Rakhmad Syafutra Lubis ${ }^{3}$

Analisis Performansi Video Streaming Dengan Menggunakan

$9-12$

Protokol RTSP Pada Jaringan IEEE 802.11n

Rahmad Rizki ${ }^{1}$, Rizal Munadi ${ }^{2}$, Syahrial $^{2}$

Pengaruh Heatsink Terhadap Kinerja Modul Surya

$13-18$

T. Mizan Sya'rani D. ${ }^{1 *}$, Ira Devi Sara ${ }^{2}$, dan Laina Hilma Sari ${ }^{3}$

Penentuan Tingkat Penyebaran Ikan Berdasarkan Citra

Suhu Permukaan Laut Di Perairan Laut Kabupaten Aceh Jaya

Menggunakan Satelit Aqua Modis

Naziran ${ }^{1}$, Rizal Munadi ${ }^{2}$, Muchlisin ${ }^{2}$

Studi Pengaruh Hibridisasi Seleksi Roullete Wheel Dengan $26-30$

Tournament Selection Menggunakan Algoritma Berevolusi Pada TSP

Cut lilis Setiawati ${ }^{1}$, Taufiq Abdul Gani ${ }^{2}$, Yuwaldi Away ${ }^{2}$

Audit Dan Optimasi Energi Listrik Pada Bangunan Kampus $31-37$

Menggunakan Metode Algoritma Genetika

Samsuddin $^{1}$, Suriadi ${ }^{2}$, Yuwaldi Away ${ }^{3}$

Aplikasi Histogram Discrete Cosine Transform (DCT) Untuk $38-42$

Sistem Temu Kembali Citra Termal Berbasis Konten

Faridah $^{1}$, Khairul Munadi ${ }^{2}$, Fitri Arnia ${ }^{3}$

Pengujian Algoritma Artificial Neural Network (ANN) $43-47$

Untuk Prediksi Kecepatan Angin

Syukri $^{1}$, Samsuddin ${ }^{2}$

Penerapan Information Retrieval Menggunakan Pemodelan $48-54$

Topik Pada Deskripsi Portal Multimedia

Indra Gita Anugrah ${ }^{1}$ dan Harunur Rosyid ${ }^{2}$

Analisa Steganografi untuk Citra Bewarna (RGB)

Menggunakan Metode Less Significant Bit (LSB)

Raihan Islamadina $^{1}$, Baihaqi $^{2}$, dan Mauzar sulistriadi ${ }^{3}$ 


\title{
Penerapan Information Retrieval Menggunakan Pemodelan Topik Pada Deskripsi Portal Multimedia
}

\author{
Indra Gita Anugrah ${ }^{1}$ dan Harunur Rosyid ${ }^{2}$ \\ 1,2 Universitas Muhammadiyah Gresik \\ Jl. Sumatera No.101, Gresik, 61121 \\ indragitaanugrah@umg.ac.id ${ }^{1}$
}

\begin{abstract}
Abstrak - Pesatnya perkembangan teknologi informasi saat ini, diikuti meningkatnya perkembangan data. Data merupakan informasi yang sangat berharga perkembangan yang semakin pesat menyebabkan kesulitan dalam pengelolaannya. Salah satu pemanfaatan data adalah penggunaan temu kembali informasi pada portal video multimedia. Semakin banyak video multimedia yang tersimpan pada repositori maka semakin sulit dalam proses pencarian. Pada proses pencarian, pengguna terkadang menginginkan korelasi diantara hasil pencarian. Untuk membentuk korelasi dari hasil pencarian, dibutuhkan sebuah pemodelan topik yang berfungsi sebagai penghubung diantara query, kata dan dokumen dari deskripsi video multimedia. Salah satu metode pemodelan topik dapat dilakukan menggunakan model Probabilistic Latent Semantic Analysis (PLSA) dengan algoritma Expectation dan Maximization (EM Algorithm). Algoritma EM merupakan algoritma untuk menduga suatu parameter, tahap awal adalah melakukan pencarian nilai ekspektasi (Expectation). Pencarian nilai ekspektasi membutuhkan topik sebagai parameter awal yang nilai parameter-parameter akan diperbaharui menggunakan algoritma Maximization. Proses pembentukan parameter awal dilakukan menggunakan algoritma Naive Bayes, dimana algoritma Naive Bayes digunakan memprediksi kejadian dimasa datang menggunakan pengalaman sebelumnya.
\end{abstract}

Kata kunci: sistem temu kembali informasi, pemodelan topik, plsa, naive bayes, algoritma em.

\section{Pendahuluan}

Portal multimedia merupakan media yang berisi berbagai jenis konten video. Semakin banyak video multimedia yang tersimpan pada repositori database maka semakin sulit dalam proses pencarian. Pada proses pencarian, pengguna terkadang menginginkan korelasi diantara hasil pencarian. Untuk membentuk korelasi dari hasil pencarian, dapat dilakukan menggunakan menggunakan pemodelan topik.

Pemodelan topik dapat dilakukan menggunakan model Probabilistic Latent Semantic Analysis (PLSA) dengan algoritma Expectation dan Maximization (EM Algorithm). Pada pemodelan topik menggunakan PLSA mampu menciptakan konteks dokumen yang dibedakan berdasarkan katakata yang memiliki banyak makna dengan mengelompokan kata-kata berdasarkan topik [1]. Algoritma EM merupakan algoritma untuk menduga suatu parameter, tahap awal adalah melakukan pencarian nilai ekspektasi (expectation). Setelah tahap expectaction dilanjutkan dengan tahap memperharui nilai parameter-parameter menggunakan algoritma Maximization [2]. Pada proses pencarian nilai ekspektasi menggunakan algoritma Naive Bayes, algoritma ini merupakan metode prediksi kelas dari sebuah data yang dikemukakan oleh Thomas Bayes. Metode Naive Bayes ini digunakan untuk memprediksi kejadian dimasa datang menggunakan pengalaman terdahulu [3].

Pembentukan topik pada pencarian video multimedia ini dibutuhkan pengguna untuk menghasilkan pencarian yang mampu menunjukan korelasi diantaranya. Dalam penelitian ini, data deskripsi dari video multimedia akan diteliti dan diambil hubungan korelasi diantara kata dan kalimat sehingga ketika dilakukan pencarian, maka sistem akan merekomendasikan video multimedia yang memiliki terkaitan berdasarkan topik atau kategorinya.

\section{Tinjauan Pustaka}

Portal multimedia merupakan media yang berisi berbagai jenis konten video. Semakin banyak video multimedia yang tersimpan pada repositori database maka semakin sulit dalam proses pencarian. Pada proses pencarian, pengguna terkadang menginginkan korelasi diantara hasil pencarian. Untuk membentuk korelasi dari hasil pencarian, dapat dilakukan menggunakan menggunakan pemodelan topik.

\subsection{Text Preprocessing (Praproses Teks)}

Tahap Text Preprocessing merupakan tahap awal pemrosesan teks dengan menghilangkan kata atau simbol yang tidak memiliki arti dan akan mempengaruhi proses pembentukan topik. Tujuan dari tahap ini adalah membentuk kumpulan term/kata dasar (corpus) yang terindeks dalam repository database. Beberapa tahapan yang dilakukan dalam text preprocessing adalah sebagai berikut:

a. Casefolding : Pada tahap ini bertujuan untuk membuat kalimat dalam satu bentuk, huruf kecil atau huruf besar, pada tahap ini dilakukan pula penghapusan karakter yang dianggap tidak perlu (contohnya: !, ?, - ,\&, dan lain-lain).

b. Extraction : Pada tahap ini bertujuan untuk memisahkan isi kalimat menjadi kata dasar yang disebut term. 
Jurnal Nasional Komputasi dan Teknologi Informasi

Vol.2 No.1, April 2018

P-ISSN 2620-8342

E-ISSN 2621-3052

c. Filtering : Pada tahap ini bertujuan untuk menghilangkan kata-kata yang tidak mempunyai makna (contohnya: dan, meskipun, atau, karena dan lain-lain).

d. Stemming : Pada tahap ini bertujuan untuk membentuk kata menjadi kata dasar (contohnya : makanan menjadi makan, jalanan menjadi jalan, percobaan menjadi coba, dan lain-lain).

\subsection{Term Weighting (Pembobotan Term)}

Pada sebuah dokumen terdiri banyak kata. Untuk mengetahui konten dari dokumen diperlukan pengetahuan untuk merepresentasikan kata-kata yang menyusunnya, hal ini dapat dilakukan dengan pemberian bobot sebuah kata dasar (term). Beberapa metode pemberian bobot term yang digunakan adalah pembobotan berdasarkan banyaknya kemunculan term dalam suatu dokumen TF (Term Frequency) dan mengklasifikasikan term dalam topik tertentu menggunakan algoritma naive bayes dan dilanjutkan menggunakan algoritma EM (Expectation dan Maximization). Pembobotan term menggunakan $T F$ (Term Frequency) dilakukan menggunakan Persamaan 1.

$$
T f=1+\log (T f)
$$

\subsection{Naive Bayes}

Algoritma Naive Bayes merupakan metode klasifikasi berdasarkan peluang dengan menghitung total keseluruhan peluang berdasarkan jumlah percobaan dengan kombinasi nilai yang muncul. Definisi lain tentang algoritma Naive Bayes menjelaskan bahwa Naive Bayes merupakan metode klasifikasi menggunakan perhitungan peluang dan statistik dengan memprediksi peluang dimasa depan berdasarkan data kejadian masa lalu [3]. Algoritma naive bayes ini sering digunakan untuk metode pembelajaran karena memiliki tingkat akurasi yang baik menggunakan perhitungan sederhana [4].

Algoritma naive bayes mengasumsikan semua atribut tidak memiliki ketergantungan dari nilai pada setiap variabel kelas [4], atau dapat dikatakan bahwa nilai probabilitas akhir merupakan hasil dari probabilitas awal yang merupakan kumpulan dari probabilitas individu. Persamaan umum dari teorema naive bayes menggunakan Persamaan 2

$$
P(H \mid X)=\frac{P(X \mid H) P(H)}{P(X)}
$$

a. $\quad X$ adalah sampel data dari kelas (label) yang belum diketahui.

b. $\quad H$ merupakan data dugaan dari kelas yang sudah diketahui.

c. $P(H)$ adalah nilai peluang dari dugaan $H$.

d. $\quad P(X)$ adalah nilai peluang sampel data yang diamati.

e. $P(X \mid H)$ adalah peluang sampel data $X$, dengan asumsi bahwa dugaan benar.

\subsection{Probabilistic Latent Semantic Analysis (PLSA)}

PLSA merupakan metode pemodelan probabilitas menggunakan distribusi mixture. Distribusi mixture merupakan sebuah model untuk menggambarkan komponen penyusun dari keseluruhan model. Dimana sebuah model komponen memiliki sub penyusun yang bervariasi sesuai dengan komponennya masing-masing [6].

PLSA merupakan model statistik dengan tujuan mencari hal yang dapat dijadikan penghubung antara dokumen dengan kata-kata hal ini dinamakan aspect model [7]. Aspect model merupakan variabel tak terlihat yang disebut latent variabel. Dalam penerapan sistem temu kembali informasi aspect model ini merupakan keyword atau kata kunci yang menghubungkan antara kata dengan dokumen. Dalam sebuah keyword terdapat topik yang merupakan penghubung diantara dokumen dengan kata.

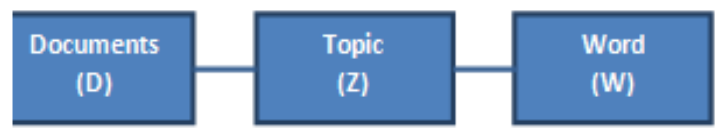

Gambar 1. Hubungan Dokumen, Topik dan Kata

Gambar 1, topik (Z) menggambarkan conditional independence yang merupakan semua variabel yang membentuk aspect model dan merupakan joint probability antara dokumen dengan kata. Conditial independent dari Gambar 1 dapat direpresentasikan menggunakan Persamaan 3 atau Persamaan 4.

$$
\begin{gathered}
P(d, w)=P(d) P(w \mid d), \\
P(w \mid d)=\sum_{z \in Z} P(w \mid z) P(z \mid d) \\
P(d, w)=\sum_{z \in Z} P(z) P(d \mid z) P(w \mid z)
\end{gathered}
$$

Model PLSA dibentuk berdasarkan kumpulan topik dengan nilai probabilitas. Tahap awal nilai probabilitas dibentuk berdasarkan beberapa cara secara acak atau ditentukan menggunakan inisialisasi dengan tujuan menghasilkan probabilitas maksimum (maximum probability) [8]. Untuk membentuk maximum probability menggunakan algoritma expectatiom and maximization. Algoritma ini terdiri dari 2 tahap yaitu:

a. Expectation, Tahap ini bertujuan untuk menemukan expectation topik menggunakan 
probabilitas awal, pada tahap ini algoritma Naive Bayes digunakan untuk mencari propabilitas awal. Setelah nilai probabilitas awal ditentukan maka akan dilanjutkan menggunakan Persamaan 5 .

$$
P(c i \mid d j)=\frac{P(c i) \prod_{k i}^{|d j|} P(c i)}{\sum_{r=1}^{|c|} P(c r) \prod_{k i}^{|d j|} P(w k j \mid c r)}
$$

$P(c i \mid d j)$ adalah probabilitas kemunculan kategori $c i$ dalam dokumen $d j$.

b. Maximization, Tahap ini bertujuan untuk memperbarui nilai parameter dari tahap expectation, Persamaan 6.

$$
P(k j \mid c i)=\frac{1+\sum_{r=1}^{|D|} N(w k j, d j) P(c i \mid d j)}{|W|+\sum_{s=1}^{|w|} \Sigma_{j=1}^{|D|} N(w s, d j) P(c i \mid d j)}
$$

$N(w k j . d j)$ adalah jumlah kata $w k$ pada dokumen $d j$.

$|W|$ adalah jumlah keseluruhan kata/fitur yang digunakan.

$|D|$ adalah jumlah seluruh training dokumen.

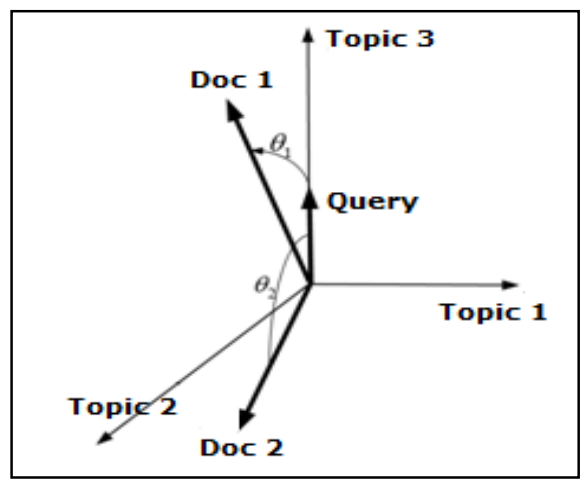

Gambar 2. Vektor Dokumen, Dokumen dan Topik

\subsection{Cosine Similarity}

Fungsi Cosine similarity secara umum merupakan metode untuk melakukan pengukuran kesamaan diantara 2 buah objek dengan nilai 0 hingga 1 . Semakin mirip 2 buah objek maka nilai kemiripan mendekati nilai 1. Sedangkan cosine similarity merupakan perhitungan kesamaan berdasarkan sudut cosine diantara 2 buah vektor yaitu vektor query dan vektor dokumen [9].

Perangkingan dilakukan untuk menentukan video multimedia mana yang memiliki kemiripan paling tinggi dengan query yang dimasukkan oleh pengguna. Penelitian ini menggunakan perhitungan mixture cosine similarity yaitu menghitung kemiripan gabungan diantara dokumen dengan query menggunakan topik. Sebelum menghitung kemiripan menggunakan mixture cosine similarity, terlebih dahulu dihitung vektor dokumen dan vektor query.

Vektor dokumen didapat dari matriks multimedia terhadap topik yang dikalikan dengan matriks diagonal bobot probabilitas topik. Gambar 2 . menunjukan similarity antara query dengan dokumen dan topik. Sudut $\theta 1$ menggambarkan similarity Doc 1 dengan query sedangkan sudut $\theta 2$ menggambarkan kemiripan dokumen Doc 2 dengan query. Perhitungan Cosine similarity dasar dilakukan menggunakan Persamaan 7

$$
\text { Similarity }(A, B)=\cos (\theta)=\frac{A \cdot B}{\|A\|\|B\|}
$$

\section{Metode Penelitian}

Pada bagian ini akan dibahas tentang alur dari pemodelan topik menggunakan Probabilistic Latent Semantic Analysis (PLSA), dimana deskripsi pada portal media akan dilakukan praproses teks terlebih dahulu dan akan menghasilkan kumpulan term yang disimpan pada corpus database.

Gambar 3 menjelaskan alur dari sistem yang akan dibangun menggunakan Probabilistic Latent Semantic Analysis (PLSA) yang akan menghasilkan bobot probabilitas dokumen deskripsi pada portal multimedia terhadap topik/kategori dan kemudian dilakukan perhitungan kemiripan antara query dengan deskripsi dokumen.

\section{Hasil dan Pembahasan}

Sistem yang dibangun adalah aplikasi dengan konsep temu kembali informasi yang dapat melakukan pencarian terhadap video nultimedia menggunakan metode pemodelan topik Probabilistic Latent Semantic Analysis (PLSA). Tujuan dari sistem ini adalah untuk membentuk korelasi diantara hasil pencarian. 


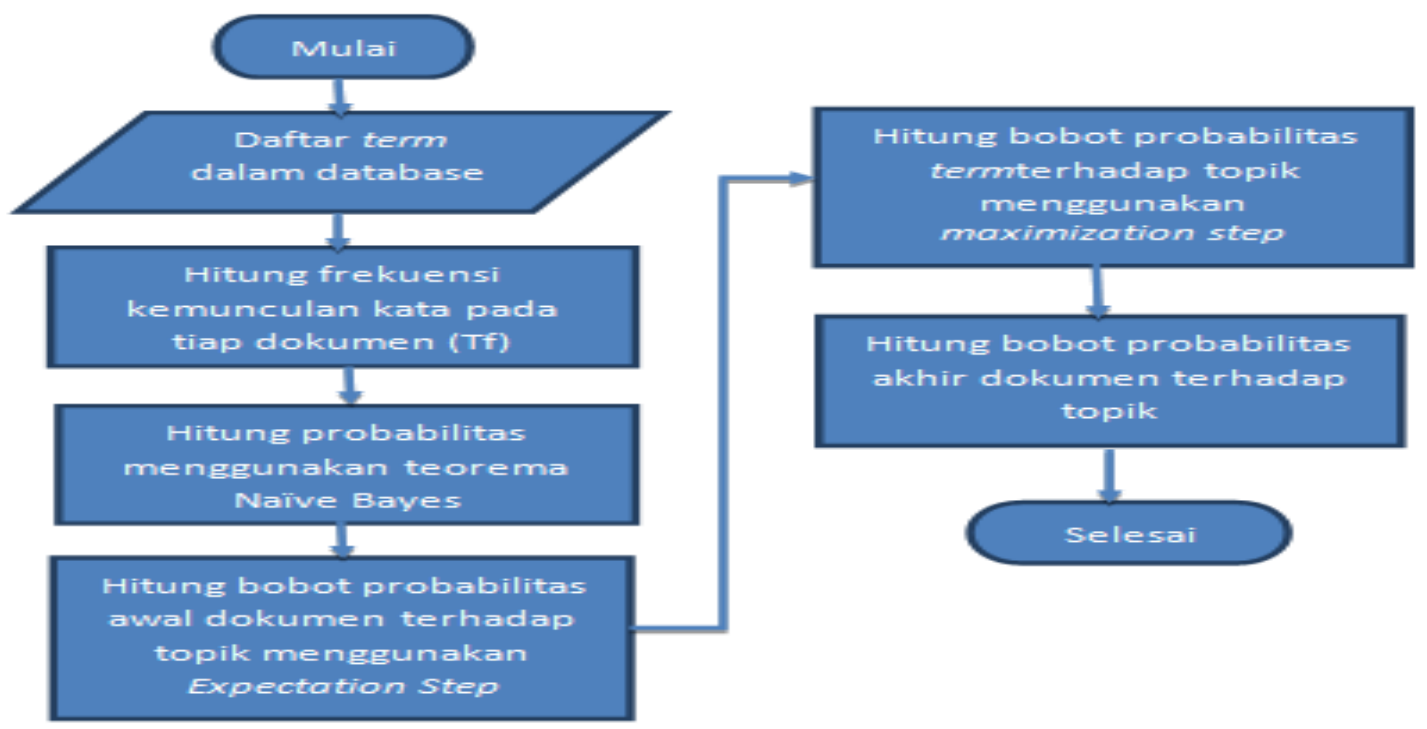

Gambar 3. Diagram Alir Pembobotan Metode Pemodelan Topik

Tahap awal akan dilakukan preprocessing yang dilakukan untuk menhilangkan kata atau simbol yang tidak memiliki arti. Tahap selanjutnya akan dilakukan pembobotan pemodelan topik. Dalam penelitian ini pembobotan menggunakan algoritma Expectation dan Maximization. Setelah proses pembobotan dalam pemodelan topik, pada proses pencarian akan dilakukan proses pencocokan dan perangkingan dari query yang dilakukan pengguna menggunakan mixture cosine similarity. Tahap implementasi Multimedia Information Retrieval menggunakan bahasa pemrograman Java.

\subsection{Dataset}

Data yang digunakan pada penelitian ini terdiri dari 30 data dengan detail kategori yang berbeda, masing-masing kategori berjumlah 10 data, baik kategori Data Mining (DM), Pengolahan Citra Digital (PCD), dan Sistem Pendukung Keputusan (SPK).

\subsection{Text Preprocessing (Stemming)}

Stemming adalah sebuah cara yang digunakan untuk mentransformasi kata-kata pada sebuah dokumen teks ke bentuk kata dasarnya. Sistem Temu Kembali Informasi Multimedia yang akan dibangun menggunakan bahasa Indonesia, sehingga menggunakan Stemming untuk bahasa Indonesia menggunakan Algoritma Nazief \& Adriani. Algoritma Nazief \& Adriani merupakan metode stemming yang dibangun berdasarkan tata bahasa bahasa Indonesia dengan memisahkan imbuhan baik awalan, akhiran maupun sisipan [10].

Dokumen uji berisikan kalimat-kalimat, dimana kalimat merupakan kumpulan dari beberapa kata atau term. Dalam sebuah dokumen juga mengandung tanda baca, angka dan kareakter lainnya. Langkah pertama dilakukan penghapusan tanda baca, angka dan karakter, setelah dilakukan proses penghapusan tahap berikutnya pemisahan (split) setiap kata dalam kalimat. Kata yang telah dipisah akan dilakukan proses penghapusan stopword (kata yang dianggap tidak penting, misalkan: dan, apa, jika, bagaimana dan lain-lain). Tahapan berikutnya kata akan dilakukan proses stemming yang bertujuan mencari kata dasar dari sebuah kata (misalkan: makanan menjadi makan, percobaan menjadi coba dan lainlain). Setelah menjadi kata dasar akan disimpan pada corpus root word yang berisi kumpulan kata-kata dasar.

Tabel 1. Pembentukan Term

\begin{tabular}{|c|c|}
\hline \multicolumn{2}{|c|}{ Pembentukan Term } \\
\hline Token & Term \\
\hline sistem & sistem \\
\hline penunjang & tunjang \\
\hline pemilihan & pilih \\
\hline terbaik & baik \\
\hline pendukung & dukung \\
\hline di buat & buat \\
\hline
\end{tabular}

\subsection{Naive Bayes}

Teorema Nä̈ve Bayes digunakan dalam penelitian ini untuk menentukan bobot probabilitas pada tahap awal Probabilistic Latent Semantic Analysis yakni tahap Expectation. Pada penelitian ini untuk mengetahui suatu dokumen bagian dari suatu kategori maka dilakukan proses klasifikasi. 


\begin{tabular}{|l|l|l|}
\hline $\begin{array}{l}\text { Dokumen } \\
\text { Multimedia }\end{array}$ & Kategori & Fitur Kemunculan \\
\hline DOKMUL1 & PCD & identifikasi(2),warna(3), olah(2) \\
\hline DOKMUL2 & DM & klasifikasi(3),cluster(2), indeks(4) \\
\hline DOKMUL3 & $?$ & klasifikasi(2),identifikasi(1), tekstur(2) \\
\hline DOKMUL4 & $?$ & Identifikasi(1),warna(2), tekstur(3) \\
\hline
\end{tabular}

Tabel 3. Bobot Probability Topik Naive Bayes

\begin{tabular}{|c|c|c|c|c|c|c|c|c|}
\hline \multirow{2}{*}{ Kategori } & \multirow{2}{*}{$\boldsymbol{p}(\boldsymbol{c i})$} & \multicolumn{7}{|c|}{$\boldsymbol{p}$ (wkj.ci) } \\
\cline { 3 - 9 } & & warna & indeks & olah & identifikasi & klasifikasi & cluster & tekstur \\
\hline PCD & $\mathbf{1 / 2}$ & $4 / 14$ & $1 / 14$ & $3 / 14$ & $3 / 14$ & $1 / 14$ & $1 / 14$ & $1 / 14$ \\
\hline DM & $\mathbf{1 / 2}$ & $1 / 16$ & $5 / 16$ & $1 / 16$ & $1 / 16$ & $4 / 16$ & $3 / 16$ & $1 / 16$ \\
\hline
\end{tabular}

Misalkan terdapat empat dokumen multimedia yang telah dilakukan preprocessing dan masingmasing memiliki 3 (tiga) buah terms yang masing memiliki frekuensi kemunculan sebagai berikut. 1. D1 : identifikasi (2), warna(3), olah(2)
2. D2 : klasifikasi(3), cluster(2), indeks(2)

3. D3 : klasifikasi(2), identifikasi(1), tekstur(2)

4. D4 : identifikasi (1), warna (2), tekstur (3) Menggunakan Persamaan 1.

\section{p(“PengolahanCitra”|"DOKMUL3”) = p(“Pengolahan Citra”) x p(“klasifikasi”|”Pengolahan Citra”) $x$ p("identifikasi”|"Pengolahan Citra") $x$ p("tekstur"|"Pengolahan Citra”) = 1/2 x 1/14 x 3/14 x 1/14= $0,000546647$.}

\section{p("Data Mining”|"DOKMUL") = p("Data Mining”) x p("klasifikasi”|" Data Mining”) $x$ p("identifikasi”|" Data Mining") x p("tekstur"|" Data Mining") = 1/2 x 4/16 x 1/16 x 1/16= $\mathbf{0 , 0 0 0 4 8 8 2 8 1 .}$}

Dari perhitungan menggunakan Persamaan 1 diketahui bahwa DOKMUL 3 termasuk dalam kategori PCD (Pengolahan Citra Digital) karena bobot probabilitas dokumen 3 terhadap kategori PCD lebih besar daripada bobot probabilitas dokumen 3 terhadap kategori DM (Data Mining) yakni $0,000546647>0,000488281$.

\subsection{PLSA (Algoritma Expectation dan Maximization)}

Nilai Probabilitas awal didapat dari perhitungan menggunakan algoritma nä̈ve bayes, nilai probabilitas tersebut diproses ke dalam data latih (training set) untuk memperoleh probabilitas yang terbaik menggunakan algoritma EM. Perhitungan pada tahap Expectation digunakan Persamaan 5.

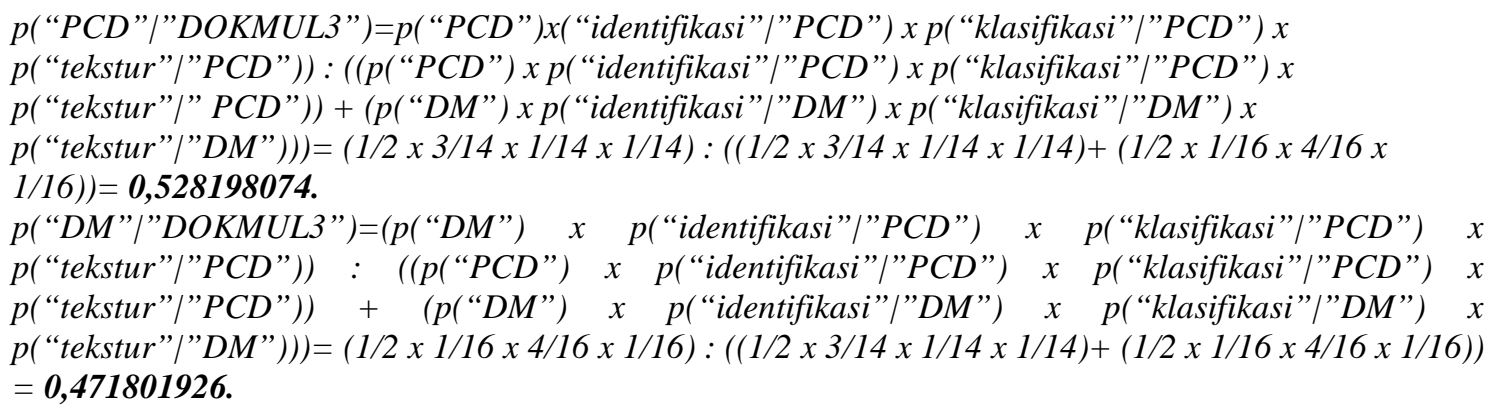

Perhitungan yang dilakukan menggunakan Persamaan 5 didapatkan nilai probabilitas total dari dua buah topik adalah 1 . Tahap berikutnya akan dicari nilai probabilitas term terbaik dari setiap topik menggunakan algoritma maximization, dihitung menggunakan Persamaan 6. Misalnya menghitung term nilai probabilitas term "warna" dari setiap topik. 
$f(p)=7+(3 \times 1)+(2 \times 0.9471)+(2 \times 1)+(2 \times 1)+(1 \times 0.5282)+(1 \times 0.9471)+(2 \times 0.4718)+$ $(2 \times 0.5282)+(3 \times 0.9472)+(2 \times 0.0528)+(4 \times 1)+(1 \times 0.4718)+(1 \times 0.0528)+(3 \times 0.0528)+$ $(2 \times 0.4718)+(2 \times 0.0528)+(2 \times 0.4718)+(3 \times 0.9471)=31.834$.

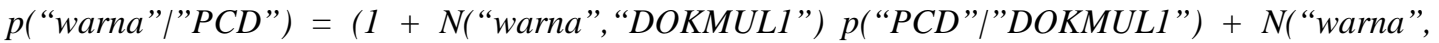

"DOKMUL2") p ("PCD”|" DOKMUL2") + N( “warna”, “DOKMUL3”) p("PCD”|" DOKMUL3”)

+ N("warna”, “DOKMUL4") $p$ ("PCD”|"DOKMUL4”)) $: f(p) p($ "warna”|" $P C D$ ") $=(1+(3 \times 1)+$ $(0 \times 0)+(0 \times 0.5282)+(2 \times 0.9471): 31.834=\mathbf{0 . 1 8 5}$.

p("warna”|"DM") = (1 + N("warna”, “DOKMUL1”) p("DM"|" DOKMUL1") +N("warna”, "DOKMUL2") p( "DM"|" DOKMUL2") + N("warna”, “DOKMUL3”) p("DM”|"DOKMUL3”) + $N($ “warna”, “DOKMUL4”) $p($ "DM"|" DOKMUL4”) $): f(p) p($ "warna”|"DM”) $=(1+(3 \times 0)+(0 \times 1)+$ $(0 \times 0.4718)+(2 \times 0.05287): 31.834=\mathbf{0 . 0 3 4 7}$.

Dari perhitungan menggunakan Persamaan 6 diketahui bahwa term "warna" dikategorikan sebagai

topik PCD (Pengolahan Citra Digital) $0.185>0.0347$.

Tabel 4. Bobot Probability Topik PLSA

\begin{tabular}{|c|c|c|c|c|c|c|c|c|}
\hline \multirow{2}{*}{ Kategori } & \multirow{2}{*}{$\boldsymbol{p}(\boldsymbol{c i})$} & \multicolumn{7}{|c|}{$\boldsymbol{p}$ (wkj.ci) } \\
\cline { 3 - 9 } & & warna & indeks & olah & identifikasi & klasifikasi & cluster & tekstur \\
\hline PCD & $\mathbf{0 , 5 3}$ & 0,185 & 0,034 & 0,094 & 0,14 & 0,064 & 0,031 & 0,154 \\
\hline DM & $\mathbf{0 , 4 7}$ & 0,035 & 0,157 & 0,031 & 0,047 & 0,155 & 0,094 & 0,066 \\
\hline
\end{tabular}

\subsection{Perhitungan Similarity}

Perangkingan dilakukan untuk menentukan dokumen mana yang memiliki kemiripan paling tinggi dengan query yang dimasukkan oleh pengguna. deskripsi video $\overbrace{\left[\begin{array}{ll}0,00101 & 0,00101 \\ 0,00003 & 0,00058 \\ 0,00058 & 0,00012 \\ 0,00165 & 0,00003\end{array}\right]}^{\text {topik }} \times \overbrace{\left[\begin{array}{ll}0,41255 & 0,00000 \\ 0,00000 & 0,25411\end{array}\right]}^{\text {probibilitas topik p(ci) }}$

$$
=\left[\begin{array}{cc}
0,00042 & 3,37 \times 10^{-6} \\
0,00001 & 0,00015 \\
0,00024 & 0,00003 \\
0,00068 & 0,00001
\end{array}\right]
$$

Gambar 4. Matriks Bobot Dokumen Terhadap Topik

Pada penelitian ini digunakan perhitungan cosine similarity untuk menghitung kemiripan dokumen dengan query. Sebelum menghitung kemiripan dengan mixture cosine similarity, terlebih dahulu dihitung vektor dokumen dan vektor query. Vektor dokumen didapat dari matriks bobot probabilitas dokumen terhapap topik yang dikalikan dengan matriks diagonal bobot probabilitas topik. Gambar 4 . menunjukan Matriks terbobot Dokumen Terhadap Topik dan kemudian akan dihitung kemiripan vektor dokumen dilakukan menggunakan Persamaan 7.

\subsection{Evaluasi Sistem}

Uji coba query ini dilakukan untuk mengukur kemampuan atau tingkat kinerja aplikasi. Dokumen yang digunakan dalam uji coba adalah isi deskripsi video multimedia di program studi teknik informatika Universitas Muhammadiyah Gresik yang berkategori Sistem Pendukung Keputusan (SPK), Data Mining (DM), dan Pengolahan Citra Digital (PCD). Sistem akan diujicobakan terhadap 30 data isi deskripsi video multimedia dan berdasarkan 6 query. Masing-masing query tersebut akan dievaluasi menggunakan nilai precision, recall, accuracy, dan fmeasure untuk mengetahui tingkat kinerja dari aplikasi. 
Tabel 5. Evaluasi Sistem

\begin{tabular}{|c|l|l|c|c|c|c|}
\hline No & \multicolumn{1}{|c|}{ Query } & Asumsi Kelas & $\begin{array}{c}\text { Precission } \\
(\boldsymbol{\%})\end{array}$ & $\begin{array}{c}\text { Recall } \\
(\boldsymbol{\%})\end{array}$ & $\begin{array}{c}\text { Accuracy } \\
(\boldsymbol{\%})\end{array}$ & $\begin{array}{c}\text { F-Measure } \\
(\boldsymbol{\%})\end{array}$ \\
\hline 1 & ekstraksi fitur warna dan tekstur & PCD & 90.9 & 100 & 96.7 & 95.2 \\
\hline 2 & pendukung keputusan & SPK & 91.7 & 100 & 96.7 & 95.7 \\
\hline 3 & klasifikasi fitur citra & PCD/DM & 86.7 & 100 & 93.3 & 92.9 \\
\hline 4 & pengelompokan kelas berdasarkan ciri & PCD/DM & 94.4 & 89.5 & 90 & 91.9 \\
\hline 5 & bobot kriteria dalam cluster & DM/SPK & 93.3 & 77.8 & 83.3 & 84.8 \\
\hline 6 & bobot atribut dalam setiap kelompok & PCD/DM/SPK & 100 & 84.2 & 90 & 91.4 \\
\hline & Rata-rata & & $\mathbf{9 2 . 8}$ & $\mathbf{9 1 . 9}$ & $\mathbf{9 1 . 7}$ & $\mathbf{9 2}$ \\
\hline
\end{tabular}

\section{Kesimpulan}

Setelah dilakukan pendefinisian masalah, analisis, pembuatan aplikasi dan percobaan, maka dapat diambil beberapa kesimpulan sebagai berikut.

1. Metode pemodelan topik menggunakan Probabilistic Latent Semantic Analysis (PLSA) dapat diimplementasikan pada Sistem Pencarian Multimedia.

2. Metode pemodelan topik ini sangat dipengaruhi corpus (kumpulan term) yang diambil dari tahap preprocessing. Semakin banyak corpus yang dihasilkan, akan semakin luas temu kembali informasi yang dihasilkan.

3. Tahap preprocessing dipengaruhi metode yang digunakan pada proses stemming kata, semakin baik sebuah metode dalam memproses kata yang memiliki imbuhan menjadi kata dasar maka akan semakin baik pula kualitas corpus yang dihasilkan.

4. Berdasarkan analisis hasil pengujian sistem, aplikasi pencarian multimedia ini menghasilkan rata-rata nilai akurasi sebesar 91,7\%, nilai precission sebesar $92,8 \%$, nilai recall sebesar $91,9 \%$, nilai f-measure sebesar $92 \%$ dari 6 kata kunci (query) yang diujikan.

\section{Daftar Pustaka}

[1] F. Revindasari, R. Sarno, and A. Solichah. Traceability Between Business Process and Software Component using Probabilistic Latent Semantic Analysis, International Conference on Informatics and Computing (ICIC), Hal 3-8. 2016.

[2] Hogg, R. V., McKean J. W., \& Craig, A. T. Introduction to Mathematical Statistics (6th ed.). United States of America : Pearson Education, Hal 359-366, 2005.

[3] Bustami., Penerapan Algoritma Naive Bayes Untuk Mengklasifikasi Data Nasabah Asuransi, TECHSI : Jurnal Penelitian Teknik Informatika, Vol. 3, No. 2, Hal. 127-146, 2013.

[4] Aggarwal, C., and C. Zhai. Mining Text Data Chapter A Survey of Text Classification
Algorithms. London : Kluwer Academics Publisher. 2012.

[5] Patil, T. R., Sherekar, M. S., Performance Analysis of Naive Bayes and J48 Classification Algorithm for Data

Classification, International Journal of Computer Science and Applications Vol. 6, No. 2, Hal 256-261, 2013.

[6] Gelman, A, Carlin, J.B, Stren, H.S, dan Rubin, D.B., Bayesian Analysis Theory and Methods. New York :Springer. 1995.

[7] Hofmann T.. Probabilistic Latent Semantic Analysis. Proceedings of the Fifteenth conference on Uncertainty in Artificial Intelligence, 1999.

[8] Claude Sammut and Geoffrey I. Webb. Encyclopedia of Machine Learning (1st ed.). Springer Publishing Company, Incorporated. Hal. 387, 2011.

[9] Iriananda, Syahroni \& Aziz Muslim, Muhammad \& Dachlan, Harry. (2018). Identifikasi Kemiripan Teks Menggunakan Class Indexing Based Dan Cosine Similarity Untuk Klasifikasi Dokumen Pengaduan. DOI:10.17605/OSF.IO/MJ5DX, 2018.

[10] D Wahyudi, T Susyanto, D Nugroho., Implementasi Dan Analisis Algoritma Stemming Nazief \& Adriani Dan Porter Pada Dokumen Berbahasa Indonesia, Jurnal Ilmiah SINUS, Vol. 15, Issue. 2, Hal. 49-56, 2017.

[11] Zulfan, and Baihaqi "Pemanfaatan Konten Multimedia Animasi Dua Dimensi sebagai Media Pelestarian Alat Musik Etnik Aceh." Jurnal Nasional Komputasi dan Teknologi Informasi (JNKTI) 1, no. 2 (2018).

[12] Zulfan, and Samsuddin "Analisa \& Perancangan Edukasi Keamanan Berlalu Lintas bagi Masyarakat Berbasis Konten Multimedia Animasi." Jurnal Serambi Engineering 1, no. 1 (2016). 
